Conclusion: Increased Tim-3 expression on neutrophils may be a novel indicator to assess disease activity and severity in AS, which may serves as a negative feedback mechanism preventing potential tissue damage caused by excessive inflammatory responses in AS patients.

REFERENCES:

[1] Han, G., Chen, G., Shen, B. \& Li, Y., Tim-3: an activation marker and activation limiter of innate immune cells. FRONT IMMUNOL 4449 (2013).

[2] Vega-Carrascal, I. et al., Galectin-9 signaling through TIM-3 is involved in neutrophil-mediated Gram-negative bacterial killing: an effect abrogated within the cystic fibrosis lung. J IMMUNOL 1922418 (2014).

Disclosure of Interests: None declared

DOI: 10.1136/annrheumdis-2021-eular.3516

\section{POS0370 TYPE I INTERFERON PATHWAY ASSAYS IN PATIENTS WITH RHEUMATIC AND MUSCULOSKELETAL DISEASES - SYSTEMATIC LITERATURE REVIEW (SLR) AND DEVELOPMENT OF CONSENSUS TERMINOLOGY FROM A EULAR TASKFORCE}

A. Burska ${ }^{1}$, J. Rodriguez Carrio ${ }^{2}$, P. G. Conaghan ${ }^{1}$, W. A. Dik ${ }^{3}$,

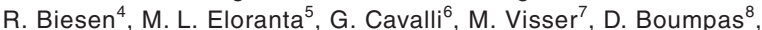
G. Bertsias ${ }^{9}$, M. Wahren-Herlenius ${ }^{10}$, J. Rehwinkel ${ }^{11}$, M. L. Frémond ${ }^{12}$, M. K. Crow ${ }^{13}$, L. Ronnblom ${ }^{5}, \mathrm{E}$. Vital $^{1}, \mathrm{M}$. Versne ${ }^{14}{ }^{1}{ }^{1}$ University of Leeds, Leeds Institute of Rheumatic and Musculoskeletal Medicine, Leeds, United Kingdom; ${ }^{2}$ University of Oviedo, Instituto de Investigación Sanitaria del Principado de Asturias (ISPA), Oviedo, Spain; ${ }^{3}$ Erasmus MC, Department of Medical Immunology, Rotterdam, Netherlands; ${ }^{4}$ Charité University Medicine Berlin, Department of Rheumatology, Berlin, Germany; ${ }^{5}$ Uppsala University, Department of Medical Sciences, Rheumatology, Uppsala, Sweden; ${ }^{6}$ Vita-Salute San Raffaele University, Unit of Immunology, Rheumatology, Allergy and Rare Diseases, Milan, Italy; ${ }^{7}$ EULAR, PARE Patient Research Partners, Amsterdam, Netherlands; ${ }^{8}$ University of Crete, Medical School, Department of Internal Medicine, Heraklion, Greece; ${ }^{9}$ University of Crete, Medical School, Department of Internal Medicine, Heraklion, Greece; ${ }^{10}$ Karolinska Institutet, Division of Rheumatology, Stockholm, Sweden ${ }^{11}$ University of Oxford, MRC Human Immunology Unit, Oxford, United Kingdom; ${ }^{12} \mathrm{Hoppital}$ Necker-Enfants Malades, Immuno-Hématologie et Rhumatologie pédiatriques, Paris, France; ${ }^{13} \mathrm{Hospital}$ for Special Surgery, Weill Cornell Medical College, Mary Kirkland Center for Lupus Research, New York, United States of America: ${ }^{14}$ Erasmus MC, Department of Immunology, Rotterdam, Netherlands

Background: The interferon (IFN) pathway is a complex system with multiple proteins and diverse downstream effects on gene and protein expression. IFNs have been implicated in multiple RMDs. Despite significant potential, IFN assays have not progressed into clinical practice.

Objectives: To perform a SLR on IFN assays in RMDs and propose a consensus terminology.

Methods: OvidMedline, Embase and Web of Science were searched for reports of IFN and RMDs up to October 2019. Information about the properties of assays measuring type I IFN and measures of truth were extracted and summarised. Terminology was agreed through an interactive consensus process with reference to the existing evidence.

Results: 10037 abstracts were identified. 275 fulfilled eligibility criteria, and were used for data extraction. Some used more than one technique to measure IFN-I pathway activation. Hence, 275 papers generated data on 393 methods. There was great heterogeneity in the methods used and presentation of results. IFN-I pathway activation was measured using: $\mathrm{PPCR}(\mathrm{n}=121)$, immunoassays $(n=101)$, microarray $(n=69)$, reporter cell assay $(n=38)$, DNA methylation $(n=14)$, flow cytometry ( $n=14)$, cytopathic effect assay $(n=11)$, RNA sequencing $(n=9)$, Plaque reduction assay $(n=8)$, Nanostring $(n=5)$, bisulphite sequencing $(n=3)$. All papers fulfilled Face Validity. Due to lack of gold standard for IFN-I pathway activation, evidence of criterion validity was variable. Concurrent validity was presented for $n=150$ assays. The terminology used to describe aspects of type I IFN pathway activation was not consistent, so a consensus terminology for IFN research (Table 1) was proposed by the taskforce.

\section{Table 1. Consensus terminology}

\begin{tabular}{|c|c|c|}
\hline Term & Abbreviation & Definition \\
\hline Interferon & IFN & $\begin{array}{l}\text { Proteins with anti-viral activity; IFNs are mediators of an } \\
\text { anti-viral response. They belong to the Type I, Type II and } \\
\text { Type III IFN families. }\end{array}$ \\
\hline Type I interferon & IFN-I & $\begin{array}{l}\text { The IFNs alpha, beta, omega, kappa, epsilon, secreted by } \\
\text { any nucleated cell, and binding to the IFNAR, which is } \\
\text { expressed on any nucleated cell. }\end{array}$ \\
\hline Type II interferon & IFN-II & $\begin{array}{l}\text { IFN gamma, mostly secreted by T cells, binding to the } \\
\text { IFNGR, which is expressed on most leucocytes. }\end{array}$ \\
\hline Type III interferon & IFN-III & $\begin{array}{l}\text { IFN lambda, which are structurally more similar to IL-10 } \\
\text { but share downstream signalling and gene expression } \\
\text { with IFN-I. }\end{array}$ \\
\hline $\begin{array}{l}\text { Interferon- } \\
\text { stimulated } \\
\text { genes }\end{array}$ & ISGs & $\begin{array}{l}\text { Genes whose expression is known to be upregulated by } \\
\text { any kind of IFN. Individual ISGs may not exclusively } \\
\text { represent Type I IFN pathway activation. }\end{array}$ \\
\hline $\begin{array}{l}\text { Type I Interferon } \\
\text { pathway } \\
\text { activation }\end{array}$ & & $\begin{array}{l}\text { Any evidence for function of the components of the Type } \\
\text { I IFN pathway. This includes: secretion of a Type I IFN } \\
\text { protein, binding to the IFNAR, initiation of JAK/STAT } \\
\text { signalling pathways, expression of IFN-stimulated genes, } \\
\text { expression of IFN-stimulated proteins. }\end{array}$ \\
\hline $\begin{array}{l}\text { Type I interferon } \\
\text { pathway assay }\end{array}$ & & $\begin{array}{l}\text { An assay measuring one or more components of the Type I } \\
\text { IFN pathway at a molecular or functional level. }\end{array}$ \\
\hline $\begin{array}{l}\text { Interferon stim- } \\
\text { ulated gene } \\
\text { expression } \\
\text { signature }\end{array}$ & & $\begin{array}{l}\text { A qualitative description of coordinated expression of a } \\
\text { set of ISGs that is indicative of Type I IFN pathway } \\
\text { activation. }\end{array}$ \\
\hline $\begin{array}{l}\text { Interferon stim- } \\
\text { ulated gene } \\
\text { expression } \\
\text { score }\end{array}$ & & $\begin{array}{l}\text { A quantitative variable derived from expression of a defined } \\
\text { set of ISGs that is indicative of Type I IFN pathway } \\
\text { activation. }\end{array}$ \\
\hline $\begin{array}{l}\text { Interferon stim- } \\
\text { ulated protein } \\
\text { score }\end{array}$ & & $\begin{array}{l}\text { A variable derived from expression of a defined set of } \\
\text { soluble biomarkers known to be upregulated by IFN, } \\
\text { although not specific for Type I IFN. }\end{array}$ \\
\hline Interferonopathy & & $\begin{array}{l}\text { Monogenic diseases in which there is constitutive Type I } \\
\text { IFN pathway activation with a causal role in pathology. } \\
\text { The clinical picture may resemble rheumatic muscu- } \\
\text { loskeletal diseases. However, most diseases with IFN } \\
\text { pathway activation are not Interferonopathies. }\end{array}$ \\
\hline
\end{tabular}

Conclusion: Diverse methods have been reported as IFN assays and these differ in what elements of type IFN-I pathway activation they measure. The task force consensus terminology on type I IFN reporting should be considered for research and clinical applications.

Disclosure of Interests: Agata Burska: None declared, Javier Rodriguez Carrio: None declared, Philip G Conaghan: None declared, Willem A Dik: None declared, Robert Biesen: None declared, Maija-leena Eloranta: None declared, Giulio Cavalli: None declared, Marianne Visser: None declared, Dimitrios Boumpas: None declared, George Bertsias: None declared, Marie Wahren-Herlenius: None declared, Jan Rehwinkel: None declared, Marie-Louise Frémond: None declared, Mary K. Crow Consultant of: AstraZeneca, Bristol Meyers Squibb, Lilly, Shannon Pharmaceuticals, Grant/ research support from: Gilead, Lars Ronnblom Consultant of: AstraZeneca, Edward Vital Speakers bureau: GSK, Consultant of: AURINIA, SANDOZ GSK, AstraZeneca, Roche, Modus, Grant/research support from: AstraZeneca, Marjan Versnel: None declared DOI: 10.1136/annrheumdis-2021-eular.3788 